\title{
PHYSIOLOGICAL AND ANATOMICAL RESPONSES TO WATER DEFICITS IN THE CAM EPIPHYTE TILLANDSIA IONANTHA (BROMELIACEAE)
}

\author{
EDWARD J. NOWAK AND CRAIG E. MARTIN' \\ Department of Botany, University of Kansas, Lawrence, Kansas 66045-2106
}

\begin{abstract}
Although physiological responses to drought have been examined in several species of epiphytic bromeliads, few have included a comprehensive methodological approach to the study of the carbon and water relations of a single species undergoing drought stress. Thus, physiological and anatomical responses to an imposed drought treatment were examined in the atmospheric Crassulacean acid metabolism (CAM) epiphyte Tillandsia ionantha. From 0 through 20 $\mathrm{d}$ without water, nocturnal malic acid accumulation and $\mathrm{CO}_{2}$ uptake rates did not change despite a $17 \%$ reduction in relative water content. In addition, water potentials averaged $-0.40 \mathrm{MPa}$ and, unlike leaf water content, did not decline. The avoidance of further declines in leaf water content was attributed to the restriction of stomatal opening to the night (a characteristic feature of CAM), to low stomatal densities and small stomatal pores, and to a thick boundary layer resulting from a dense foliar trichome cover. The maintenance of high physiological activity during the first $20 \mathrm{~d}$ of the drought treatment was most likely a result of the high water potentials in the chlorenchyma, which were attributed, in part, to water movement from the water-storage parenchyma (= "hydrenchyma") to the chlorenchyma. Nocturnal malic acid accumulation and the rate of net $\mathrm{CO}_{2}$ exchange declined in a linear fashion from 30 to $60 \mathrm{~d}$ without water, as did leaf water potential and osmotic potential. During this time, $\mathrm{CO}_{2}$ recycling increased from ca. $20 \%$ to nearly $75 \%$. Though declining throughout this later stage of the drought treatment, metabolic activity remained relatively high, possibly as a result of the observed osmotic adjustment as well as a potentially high cell wall elasticity.
\end{abstract}

\section{Introduction}

Epiphytes play a prominent role in the diversity of the world's flora, accounting for as much as $10 \%$ of all vascular species (Kress 1989). Some of the most well-known and best-studied epiphytes are in the Bromeliaceae, especially in the genus Tillandsia (Benzing 1986). Epiphytic bromeliads can be divided into "tank" or "atmospheric" types, depending on their ability to impound water (Benzing 1980, 1986). Tank epiphytes collect water via water-retaining bases of overlapping leaves arranged in a rosette and subsequently absorb it through epidermal trichomes on the adaxial side of the leaf bases (Benzing 1986; Nyman et al. 1987). Atmospheric epiphytes lack the structures to trap external water; instead, they rely on a dense cover of large epidermal trichomes that absorb water (and nutrients) when the leaf surfaces are wet.

Because of their inability to access a consistent water supply (due to their lack of absorptive roots or the tank morphology), atmospheric epiphytes are potentially more susceptible to drought stress (Adams and Martin 1986; Benzing 1986). Tree canopies may become relatively arid habitats between rainfall events (Richards 1952; Gessner 1956). This exposure to potentially frequent drought stress in otherwise moist regions, e.g., tropical and subtropical portions of the Americas, has stimulated interest in the ecophysiology and drought resistance of atmospheric bromeliads (see Martin 1994).

Past research on the water relations and photosynthetic responses to drought in atmospheric species of Tillandsia has resulted in four major findings. First,

'Author for correspondence and reprints. Fax 913-864-5321; E-mail ecophys@falcon.cc.ukans.edu.

Manuscript received December 1996; revised manuscript received May 1997. most or all atmospheric epiphytes, at least in the genus Tillandsia, are Crassulacean acid metabolism (CAM) plants (Martin 1994). Second, these plants are able to withstand relatively large diel and seasonal changes in tissue water content (Penfound and Deiler 1947; Biebl 1964; Benzing and Dahle 1971; Martin et al. 1981; Martin and Schmitt 1989). Third, despite prolonged periods of drought stress, water and osmotic potentials of these species are seldom lower than $-1.0 \mathrm{MPa}$ (Harris 1918; Biebl 1964; Smith et al. 1985; Smith et al. 1986a; Griffiths et al. 1989; see Martin 1994). Fourth, rates of nocturnal $\mathrm{CO}_{2}$ exchange remain unaffected well into a drought and remain positive even at considerable water deficits (Benzing and Dahle 1971; Martin and Adams 1987; Griffiths et al. 1989; Martin and Schmitt 1989).

Problems in generalizing the results of past research on the carbon and water relations of epiphytic bromeliads during desiccation treatments reflect the limited number of comprehensive studies. For example, the four major findings discussed above were culled from various studies of different species; few individual studies have included a comprehensive methodological approach to the study of the carbon and water relations of one or more epiphytes.

The main objective of this research was to determine the degree to which several anatomical and water relations parameters changed relative to changes in metabolic activity in response to drought stress in Tillandsia ionantha, an atmospheric epiphyte with CAM, in order to better understand how atmospheric epiphytes tolerate periods of drought. Leaf water potential and osmotic potential, leaf relative water content, diel net $\mathrm{CO}_{2}$ exchange, nocturnal malic acid accumulation, and amount of leaf water-storage parenchyma (= "hydrenchyma") and of leaf chlorenchyma were measured throughout a 60-d drought treatment. 


\section{Material and methods}

\section{PLANTS}

Individuals of Tillandsia ionantha Planchon (Bromeliaceae) were obtained from the Marie Selby Botanical Gardens (Sarasota, Fla.) in 1988 and were subsequently maintained in a greenhouse at the University of Kansas. Environmental conditions in the greenhouse were ca. 500$1000 \mu \mathrm{mol} \mathrm{m} \mathrm{m}^{-2} \mathrm{~s}^{-1}$ maximum photosynthetic photon flux density (PPFD), $27^{\circ} / 20^{\circ} \mathrm{C}$ average day/night air temperatures, and $50 \% / 80 \%$ average day/night relative humidities. Plants were watered daily with a dilute fertilizer solution (20\% $\mathrm{N}, 18 \% \mathrm{P}_{2} \mathrm{O}_{5}, 18 \% \mathrm{~K}_{2} \mathrm{O}$, including micronutrients).

Prior to the experiments, plants were soaked in deionized water for $1 \mathrm{~h}$, then allowed to surface dry. Water $(\Psi)$ and osmotic $\left(\Psi_{\pi}\right)$ potentials, chlorenchyma and hydrenchyma tissue areas, and relative water content (RWC) were subsequently determined. Plants were returned to the greenhouse, where water was withheld for specific periods of time up to $60 \mathrm{~d}$. Four different plants were used for each drought treatment. Eight plants were kept well-watered and served as controls; four of these were measured before the drought treatment was imposed, and four were measured at the end of the drought treatment. All data from the two sets of control plants were not significantly different; therefore, data from all control plants were pooled.

\section{ChLORENCHYMA AND HYDRENCHYMA AREA DETERMINATION}

Following hydration, one leaf was harvested from each plant. Concurrently, another morphologically identical leaf was marked with ink to be excised after the drought treatment. Once excised, a thin $(<1 \mathrm{~mm})$ cross section was taken from the middle of the leaf and placed in oil on a microscope slide. The image of the section was then projected onto paper for tracing. Both chlorenchyma and hydrenchyma segments were traced. These regions are quite well-defined in $T$. ionantha (see Loeschen et al. 1993 for a representative photomicrograph of a leaf cross section). Subsequently, the areas of the tracings were determined with a LI-COR (Lincoln, Nebr.) LI-3000 Portable Area Meter.

\section{$\mathrm{CO}_{2}$ EXCHANGE}

Rates of net $\mathrm{CO}_{2}$ exchange of two plants were monitored simultaneously for $48 \mathrm{~h}$. Details of the open-flow gas exchange system, cuvettes, and infrared gas analyzer have been reported previously (Gravatt and Martin 1992). Cuvette environmental conditions were maintained at $1000 \mu \mathrm{mol} \mathrm{m} \mathrm{m}^{-2}$ $\mathrm{s}^{-1}$ PPFD (cuvette interior), 12-h photoperiod, $30^{\circ} / 20^{\circ} \mathrm{C}$ day/ night air temperatures, and 50\%/80\% day/night relative humidities. To allow time for acclimation, only data from the second 24-h period were used in the gas exchange calculations (using equations of Šesták et al. [1971] and Farquhar and Sharkey [1982]). Prior to the end of the second light period, plants were removed from the cuvettes and weighed for calculation of RWC (see below), and two leaves were removed from each plant for determinations of chlorenchyma and hydrenchyma tissue areas, water and osmotic potentials, and malic acid concentrations. Plants were then replaced in the gas exchange cuvettes (sampling typically required $10 \mathrm{~min}$ ). The following morning, plants were once again sampled for malic acid analysis and subsequently placed into an oven at $65^{\circ} \mathrm{C}$. Plant dry mass was determined when no further loss in weight could be detected.

\section{MALIC ACID ANALYSIS}

Leaf samples (for malic acid and osmotic potential determinations) were weighed and immediately frozen at $-65^{\circ} \mathrm{C}$ for at least $2 \mathrm{~d}$. Leaf sap of the thawed and sliced tissue was extracted by centrifugation (see Smith and Lüttge 1985) and analyzed for malic acid concentration using the enzymatic/ spectrophotometric method of Gutmann and Wahlefeld (1974). Tissue malic acid concentrations were calculated using standard curves based on known malic acid concentrations.

\section{DETERMINATION OF RELATIVE WATER CONTENT, WATER POTENTIAL, AND OSMOTIC POTENTIAL}

Relative water content ([fresh mass $_{\text {final }}$ - dry mass final $\left._{\text {f }}\right] /$ [fresh mass $_{\text {initial }}-$ dry mass final $_{\text {f }}$ × 100) was determined by weighing individual plants on an analytical balance throughout the drought treatment ("initial" mass determined for plants after soaking in water; "final" mass determined for different plants at each stage of the drought treatment). The water potentials of leaves of all individuals (before and after drought treatments) were determined using the Shardakov method (Slavík 1974) with solutions of polyethylene glycol 8000 (PEG). Water potentials of the PEG solutions were determined with a Wescor (Logan, Utah) HR-33T Dew Point Microvoltmeter and C-52 Sample Chamber (thermocouple psychrometer) using the dew point method. Standards $(\mathrm{NaCl}$ solutions) of known water potentials were used to calibrate the instrument. Approximately $0.02 \mathrm{~g}$ of tissue collected immediately before "lights-out" (see above) was immersed in $2 \mathrm{~mL}$ of each of the PEG solutions for $6 \mathrm{~h}$ overnight (Slavík 1974). The high ratio of tissue volume (and exchange surface) to solution volume maximized the resolution of the Shardakov technique (Slavík 1974). Determinations of leaf water potential were then made the next morning. Osmotic potentials of the cell sap extracted for the morning malic acid analyses (see above) were determined by thermocouple psychrometry as described above.

\section{Statistical ANALYSIS}

Because sample sizes were small and the data were often not normally distributed or homoscedastic, all data were rank-transformed before the application of parametric statistics (see Conover and Iman 1981; Potvin and Roff 1993). Differences among means were tested for significance using an analysis of variance, followed by the GT2-method multiple comparison of means test. All statistical tests were performed according to Sokal and Rohlf (1981); significance was inferred when $P \leq 0.05$.

\section{Results}

\section{WATER RELATIONS DURING THE DROUGHT TREATMENT}

The relative water content of Tillandsia ionantha decreased almost linearly with increasing drought stress (fig. 1). After $60 \mathrm{~d}$ of the drought treatment, individuals lost half of their maximum water content. In contrast, leaf water potentials and osmotic potentials did not differ significantly in the first half of the drought period (figs. 2, 3). Throughout this time, water and osmotic potentials averaged -0.40 and -0.47 $\mathrm{MPa}$, respectively. Water potentials began to decrease gradually from $-0.42 \mathrm{MPa}$ after $30 \mathrm{~d}$ without water to $-0.64 \mathrm{MPa}$ after $60 \mathrm{~d}$ of drought treatment (fig. 2), 


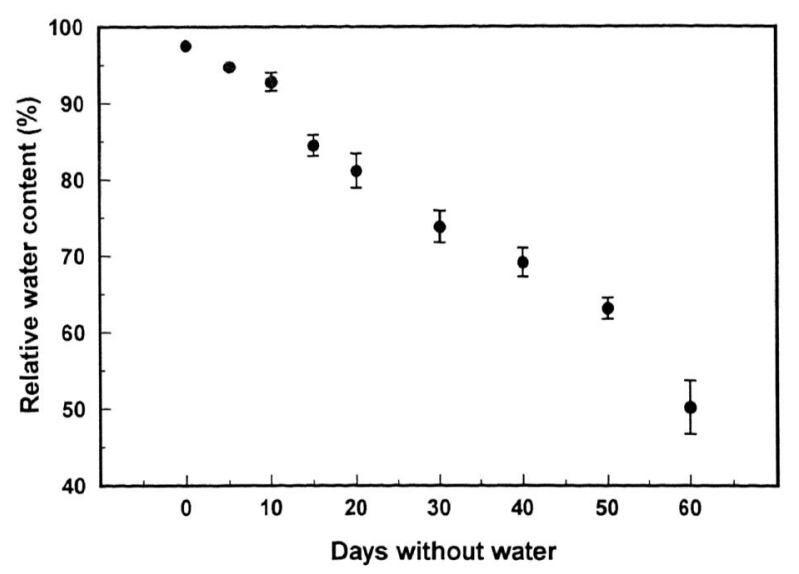

Fig. 1 Effects of a 60-d drought treatment on the relative water content of leaves of Tillandsia ionantha that were desiccated in a greenhouse. Values are means ( \pm standard deviations) of four plants, except eight plants were used at $0 \mathrm{~d}$ without water. Absence of an error bar indicates that the standard deviation was smaller than the symbol. Relative water content means are significantly different $(P$ $\leq 0.05$ ) if they do not share the same letter in the superscripts for their corresponding values of "days without water": $0^{\mathrm{a}}, 5^{\mathrm{b}}, 10^{\mathrm{bc}}$, $15^{\mathrm{cde}}, 20^{\mathrm{ef}}, 30^{\mathrm{fg}}, 40^{\mathrm{gh}}, 50^{\mathrm{hi}}, 60^{\mathrm{i}}$.

a change of ca. $50 \%$. Osmotic potentials decreased rapidly during the same period, from -0.47 to -0.74 $\mathrm{MPa}$, nearly a $60 \%$ change (fig. 3). Calculations of pressure potentials during the drought treatment revealed considerable variability, with values ranging from 0.1 to $1.0 \mathrm{MPa}$.

\section{LEAF ANATOMY DURING THE DROUGHT TREATMENT}

Based on cross sections taken at the middle of the leaf of well-hydrated plants, ca. two-thirds of the leaf is composed of chlorenchyma, whereas the remaining one-third is made up of hydrenchyma tissue. No other tissues contribute substantially to the leaf volume. The volume of the hydrenchyma tissue, expressed as a percentage of the initial cross-sectional area of the hy-

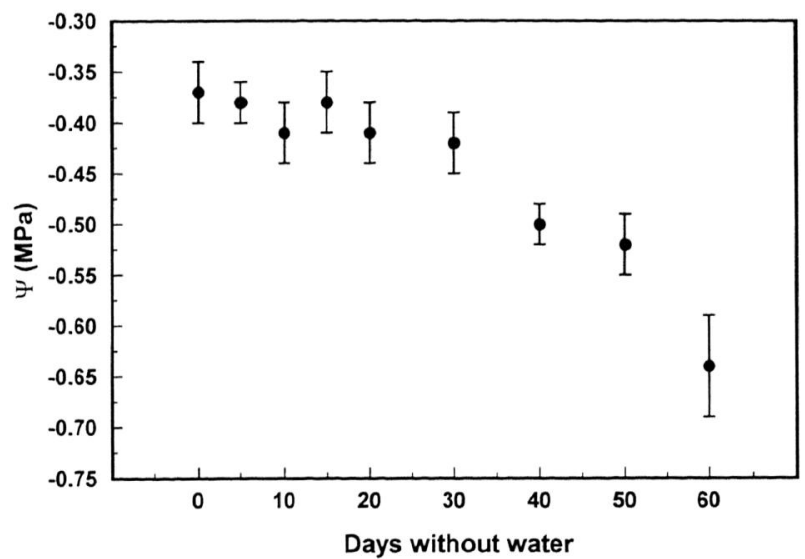

Fig. 2 Effects of a 60-d drought treatment on the water potential of leaves of Tillandsia ionantha that were desiccated in a greenhouse. Values are means ( \pm standard deviations) of four plants, except eight plants were used at $0 \mathrm{~d}$ without water. Water potential means are significantly different $(P \leq 0.05)$ if they do not share the same letter in the superscripts for their corresponding values of “days without water": $0^{\mathrm{a}}, 5^{\mathrm{a}}, 10^{\mathrm{ac}}, 15^{\mathrm{ab}}, 20^{\mathrm{ac}}, 30^{\mathrm{ac}}, 40^{\mathrm{bc}}, 50^{\mathrm{c}}, 60^{\mathrm{c}}$.

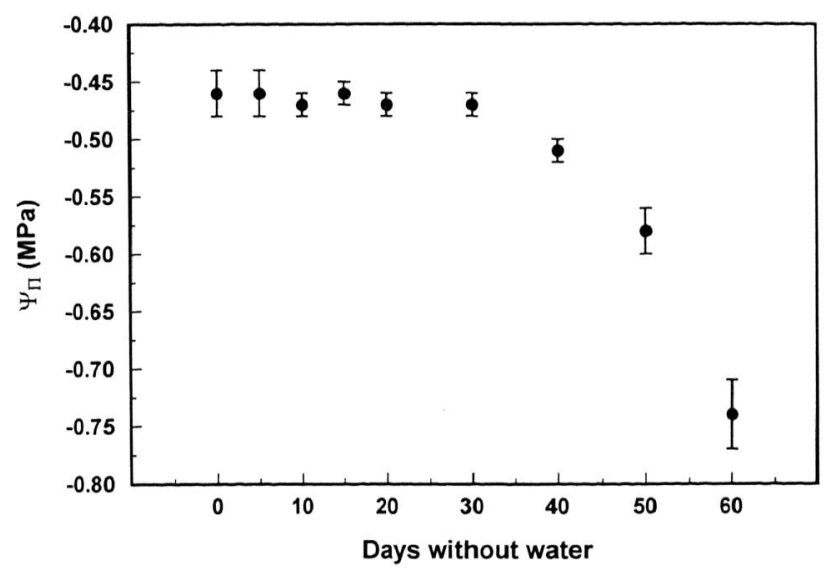

Fig. 3 Effects of a 60-d drought treatment on the osmotic potential of leaves of Tillandsia ionantha that were desiccated in a greenhouse. Values are means ( \pm standard deviations) of four plants, except eight plants were used at $0 \mathrm{~d}$ without water. Osmotic potential means are significantly different $(P \leq 0.05)$ if they do not share the same letter in the superscripts for their corresponding values of “days without water": $0^{\mathrm{a}}, 5^{\mathrm{ab}}, 10^{\mathrm{ac}}, 15^{\mathrm{a}}, 20^{\mathrm{ad}}, 30^{\mathrm{ad}}, 40^{\mathrm{ad}}, 50^{\mathrm{cd}}, 60^{\mathrm{bcd}}$.

drenchyma (not of the whole leaf area), decreased rapidly from $100 \%$ at $0 \mathrm{~d}$ without water to $0 \%$ after $50 \mathrm{~d}$ of the drought treatment (fig. 4). The relative crosssectional area of the chlorenchyma, in contrast, decreased relatively slowly during this same period. Water from the hydrenchyma was completely exhausted when the relative water content and water potential of these plants averaged ca. $63 \%$ and $-0.52 \mathrm{MPa}$, respectively (cf. fig. 4 with figs. 1, 2). At this time, the cross-sectional area of the chlorenchyma had declined by only $12 \%$.

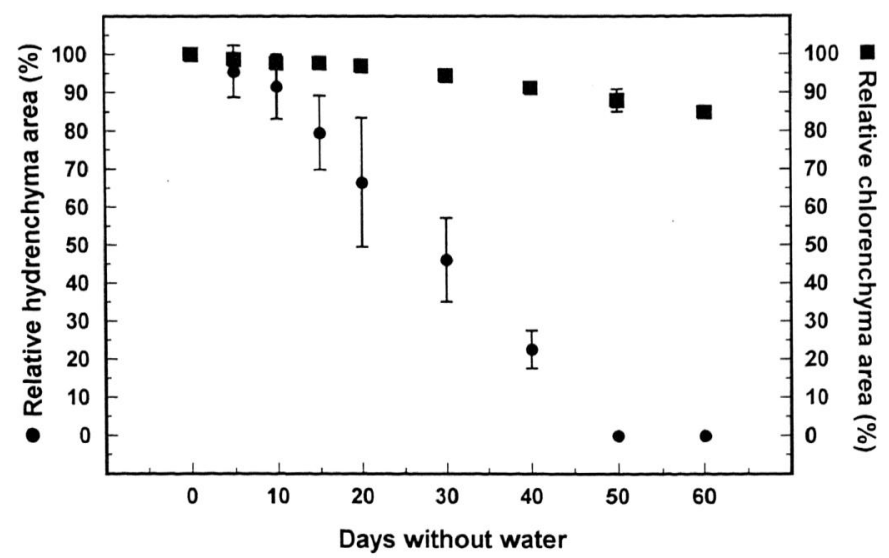

Fig. 4 Effects of a 60-d drought treatment on the relative amounts of leaf chlorenchyma and hydrenchyma, expressed as percentage of the initial volume of that particular tissue type (the chlorenchyma and hydrenchyma of well-watered plants made up ca. two-thirds and one-third of the leaf cross-sectional area, respectively), of midsections of leaves of Tillandsia ionantha that were desiccated in a greenhouse. Values are means ( \pm standard deviations) of four plants, except eight plants were used at $0 \mathrm{~d}$ without water. Absence of an error bar indicates that the standard deviation was smaller than the symbol. Chlorenchyma and hydrenchyma means are significantly different $(P \leq 0.05)$ if they do not share the same letter in the superscripts for their corresponding values of "days without water": chlorenchyma: $0^{\mathrm{a}}, 5^{\mathrm{ab}}, 10^{\mathrm{bc}}, 15^{\mathrm{bc}}, 20^{\mathrm{bc}}, 30^{\mathrm{cd}}, 40^{\mathrm{de}}, 50^{\mathrm{de}}, 60^{\mathrm{c}}$; hydrenchyma: $0^{\mathrm{a}}, 5^{\mathrm{ab}}, 10^{\mathrm{ab}}, 15^{\mathrm{bc}}, 20^{\mathrm{cd}}, 30^{\mathrm{cd}}, 40^{\mathrm{d}}, 50^{\mathrm{e}}, 60^{\mathrm{e}}$. 


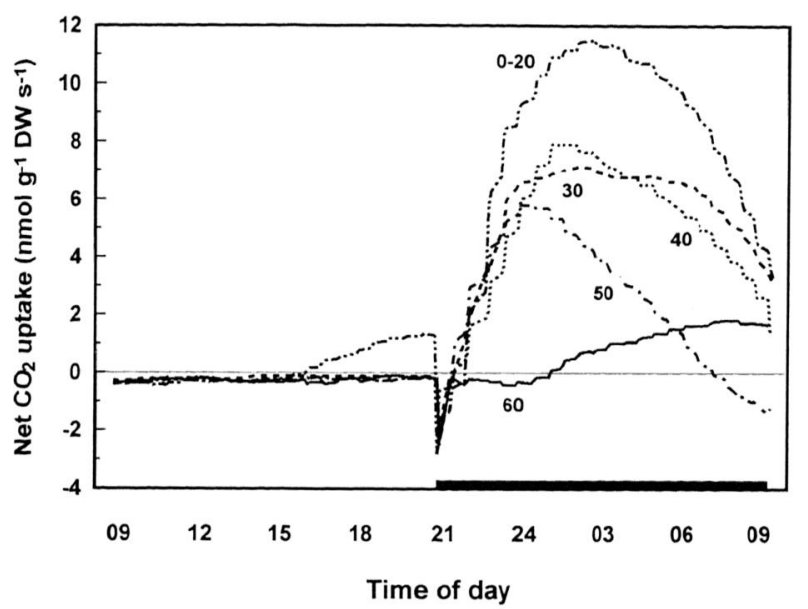

Fig. 5 Effects of a 60-d drought treatment on diel net $\mathrm{CO}_{2}$ exchange rates of plants of Tillandsia ionantha that were desiccated in a greenhouse. Numbers next to each gas exchange curve represent the number of days without water. Curves for $30,40,50$, and $60 \mathrm{~d}$ without water are mean curves of four plants. Because mean integrated nocturnal $\mathrm{CO}_{2}$ uptake values at $0 \mathrm{~d}(n=8$ plants $)$ and at 5 , 10,15 , and $20 \mathrm{~d}$ (all $n=4$ ) without water were not significantly different, only data for $0 \mathrm{~d}$ without water are shown (labeled $0-20$ ). Integrated nocturnal $\mathrm{CO}_{2}$ uptake data for these plants are given in fig. 6 .

\section{NeT $\mathrm{CO}_{2}$ EXCHANGE AND MALIC ACID ACCUMULATION DURING THE DROUGHT TREATMENT}

Individuals of $T$. ionantha maintained high positive rates of net $\mathrm{CO}_{2}$ exchange at night for $20 \mathrm{~d}$ without water (fig. 5). These plants also exhibited late afternoon $\mathrm{CO}_{2}$ uptake (Phase 4; see Osmond 1978). After 30 and $40 \mathrm{~d}$ without water, maximum net $\mathrm{CO}_{2}$ uptake rates declined by ca. one-third. With increasing water loss, late afternoon $\mathrm{CO}_{2}$ uptake was absent. After 50 d without water, maximum rates of $\mathrm{CO}_{2}$ uptake decreased by nearly $50 \%$ relative to well-watered plants. By the end of the drought treatment, maximum $\mathrm{CO}_{2}$ uptake rates were low but still positive $(18 \%$ of those of well-watered plants). Rates of net $\mathrm{CO}_{2}$ exchange were near zero during the initial portion of the dark period. Changes in the amounts of $\mathrm{CO}_{2}$ absorbed by the plants throughout the night reflected the changes in instantaneous rates of net $\mathrm{CO}_{2}$ exchange. Values of integrated nocturnal $\mathrm{CO}_{2}$ uptake from 0 through $20 \mathrm{~d}$ without water (from $98 \%$ to $81 \%$ relative water content) were not significantly different (fig. 6). At $50 \mathrm{~d}$ without water $(63 \%$ relative water content), however, integrated $\mathrm{CO}_{2}$ uptake declined to ca. $40 \%$, relative to well-watered plants. At the $60-\mathrm{d}$ treatment $(50 \%$ relative water content), integrated $\mathrm{CO}_{2}$ uptake decreased to $9 \%$ of values for well-watered plants.

Throughout the drought treatment, the relative changes in rates of $\mathrm{CO}_{2}$ uptake and in leaf water potentials were similar, while changes in plant relative water content were less so (cf. fig. 6 with figs. 1, 2). For example, a decrease in water potential of ca. 0.10 $\mathrm{MPa}$ was accompanied by a decrease in nocturnal $\mathrm{CO}_{2}$ uptake of ca. one-third, whereas leaf relative water content did not change during this time. Upon further

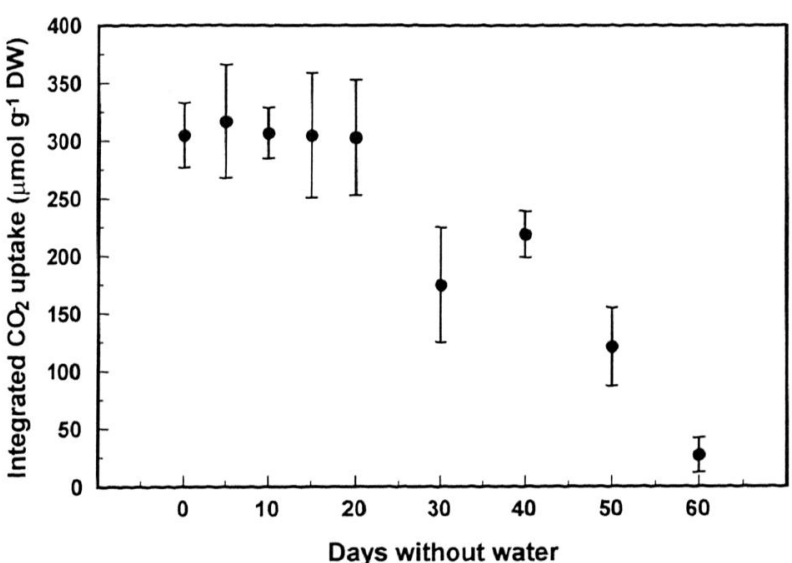

Fig. 6 Effects of a 60-d drought treatment on integrated nocturnal $\mathrm{CO}_{2}$ uptake of plants of Tillandsia ionantha that were desiccated in a greenhouse. Values are means ( \pm standard deviations) of four plants, except eight plants were used at $0 \mathrm{~d}$ without water. Integrated $\mathrm{CO}_{2}$ uptake means are significantly different $(P \leq 0.05)$ if they do not share the same letter in the superscripts for their corresponding values of "days without water": $0^{\mathrm{a}}, 5^{\mathrm{a}}, 10^{\mathrm{a}}, 15^{\mathrm{ab}}, 20^{\mathrm{abc}}, 30^{\mathrm{bd}}, 40^{\mathrm{ad}}$, $50^{\text {cd }}, 60^{\text {d. }}$. Diel net $\mathrm{CO}_{2}$ exchange curves are given in fig. 5 .

loss of water, a decrease of only $0.27 \mathrm{MPa}$ in water potential resulted in a near elimination of $\mathrm{CO}_{2}$ uptake.

The relative cross-sectional area of the chlorenchyma decreased slowly during the drought treatment, while changes in the relative cross-sectional area of the hydrenchyma were much larger. Integrated $\mathrm{CO}_{2}$ uptake did not decline until the cross-sectional area of the hydrenchyma decreased by $54 \%$ (cf. fig. 6 with fig. 4). In addition, positive integrated $\mathrm{CO}_{2}$ uptake was still observed when the area of the hydrenchyma was not measurable. In contrast, integrated $\mathrm{CO}_{2}$ uptake declined significantly when the cross-sectional area of the chlorenchyma decreased by only $6 \%$. A $15 \%$ decline in chlorenchyma area corresponded to a $91 \%$ reduction in the total amount of $\mathrm{CO}_{2}$ assimilated at night.

Nighttime malic acid accumulations remained high throughout the drought treatment until $50 \mathrm{~d}$ without water, when values decreased by ca. one-third (fig. 7). Malic acid accumulation declined by $75 \%$ after $60 \mathrm{~d}$ without water. The degree of $\mathrm{CO}_{2}$ recycling increased with increasing length of the drought treatment (fig. 8). From 0 through $20 \mathrm{~d}$ without water, the degree of $\mathrm{CO}_{2}$ recycling averaged $22 \%$. From 30 to $50 \mathrm{~d}$ of the drought treatment, ca. half of the malic acid synthesized at night was attributable to recycling of respiratory $\mathrm{CO}_{2}$. This value increased to $73 \%$ by the end of the drought treatment.

\section{Discussion}

\section{GENERAL EFFECTS OF THE DROUGHT TREATMENT}

Because sample sizes were small (usually four plants) and variability among the individuals was relatively high, some means were not significantly different in spite of large apparent differences. This was particularly true for the water and osmotic potential data, as well as for the malic acid data. The high variability in the water and osmotic potential data was ex- 


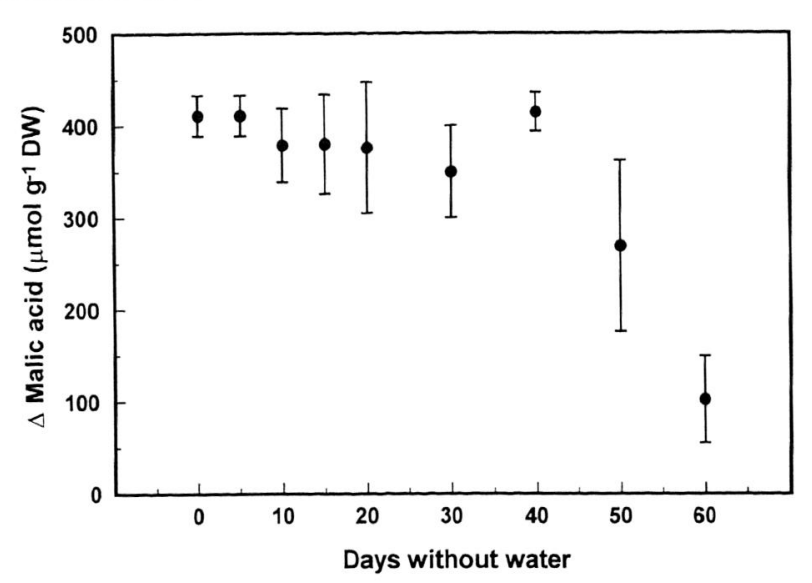

Fig. 7 Effects of a 60-d drought treatment on the nocturnal accumulation of malic acid in leaves of Tillandsia ionantha that were desiccated in a greenhouse. Values are means ( \pm standard deviations) of four plants, except eight plants were used at $0 \mathrm{~d}$ without water. Malic acid accumulation means are significantly different $(P$ $\leq 0.05$ ) if they do not share the same letter in the superscripts for their corresponding values of "days without water": $0^{\mathrm{a}}, 5^{\mathrm{ab}}, 10^{\mathrm{ab}}$, $15^{\mathrm{ab}}, 20^{\mathrm{ab}}, 30^{\mathrm{ab}}, 40^{\mathrm{a}}, 50^{\mathrm{ab}}, 60^{\mathrm{b}}$.

acerbated by the small range of values measured in these water relations parameters. As has been found in many studies of epiphytic bromeliads, tissue water and osmotic potentials seldom vary more than several tenths of a megapascal during droughts (Martin 1994). Because of this, calculations of pressure potentials from these data were considered general estimates only. For this reason, only the range of pressure potential values during the drought treatment is presented in the text, and the data were not statistically analyzed. In spite of the high variability of the data, the discussions below, which focus on the overall trends in the data, are always based on some statistically significant differences among the mean responses to the drought treatment.

\section{COMPARISONS OF RESULTS WITH PREVIOUS STUDIES}

The large changes in leaf water content reported for Tillandsia ionantha in this study are similar to those observed in the same species by Benzing and Dahle (1971) as well as those reported for Tillandsia usneoides (Martin and Schmitt 1989) and Tillandsia schiedeana (Martin and Adams 1987). Likewise, the water and osmotic potentials measured in $T$. ionantha throughout the imposed drought treatment are comparable to those reported for this species as well as for other epiphytic bromeliads in other studies (Harris 1918; Biebl 1964; Smith et al. 1985; Griffiths et al. 1986; Lüttge et al. 1986; Smith et al. 1986b). Similarly, turgor pressures in these plants are typically relatively low, as reported here. Measures of CAM (overnight increases in malic acid content and nocturnal rates of $\mathrm{CO}_{2}$ exchange) for well-watered $T$. ionantha in this study are similar to those observed previously in this species (Loeschen et al. 1993) and are substantially higher than values reported for other epiphytic bromeliads (Martin and Adams 1987; Loeschen et al. 1993; Martin 1994).

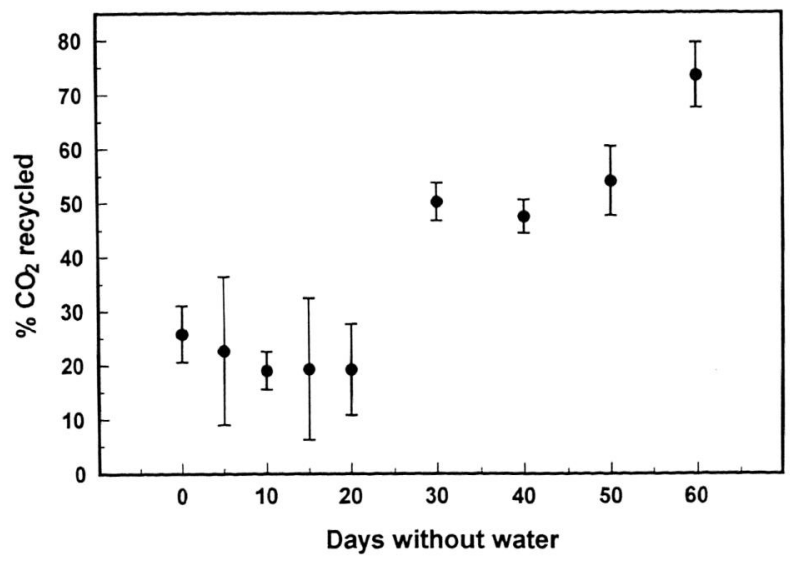

Fig. 8 Effects of a 60-d drought treatment on the amount of $\mathrm{CO}_{2}$ recycled at night in leaves of Tillandsia ionantha that were desiccated in a greenhouse. Values are means ( \pm standard deviations) of four plants, except eight plants were used at $0 \mathrm{~d}$ without water. Recycling was calculated by subtracting the amount of atmospheric $\mathrm{CO}_{2}$ absorbed at night from the amount of malic acid accumulated that night and dividing the result by the nocturnal accumulation of malic acid and expressing the result as a percentage. Thus, a recycling value of $100 \%$ indicates that an accumulation of malic acid was measured but no $\mathrm{CO}_{2}$ was taken up that night. $\mathrm{CO}_{2}$ recycling means are significantly different $(P \leq 0.05)$ if they do not share the same letter in the superscripts for their corresponding values of "days without water": $0^{\text {abce }}, 5^{\text {abcef }}, 10^{\mathrm{c}}, 15^{\text {bce }}, 20^{\text {ce }}, 30^{\text {adf }}, 40^{\text {ade }}, 50^{\text {df }}$, $60^{\mathrm{df}}$.

The effects of drought stress on CAM in T. ionantha in the current study contrast with those reported by Benzing and Dahle (1971). In the latter study, a 50\% loss in the initial water content of the plants resulted in a $25 \%-35 \%$ reduction in photosynthesis, measured as daytime $\mathrm{O}_{2}$ evolution. In the current study, an equivalent loss in water resulted in a $92 \%$ reduction in $\mathrm{CO}_{2}$ exchange. Experimental conditions in the study by Benzing and Dahle (1971) were substantially different, however, from those commonly found in the field, while in the current study an attempt was made to maintain environmental conditions as close to natural as possible; therefore, the results presented here are perhaps more applicable to $T$. ionantha individuals in the field. If so, this atmospheric epiphyte is apparently not quite as resistant to drought as was previously thought (Benzing and Dahle 1971).

Despite quantitative differences in the results, the overall patterns of metabolic responses to drought stress observed in this study are remarkably similar to those reported for $T$. ionantha by Benzing and Dahle (1971), as well as for other species of Tillandsia (Martin and Adams 1987; Martin and Schmitt 1989). Specifically, nocturnal $\mathrm{CO}_{2}$ uptake rates were unaffected during the initial stages of drought stress (over a wide range of water contents), then decreased significantly after $20 \mathrm{~d}$ of the drought treatment. Nocturnal $\mathrm{CO}_{2}$ uptake rates were also not substantially affected until water was withheld from individuals of $T$. schiedeana for $23 \mathrm{~d}$ (Martin and Adams 1987). In contrast, nocturnal integrated $\mathrm{CO}_{2}$ uptake in $T$. usneoides decreased considerably after only $4 \mathrm{~d}$ without water (Martin and Schmitt 1989). Water content during this time period, 
however, declined $19 \%$, which is also comparable to the change in relative water content that accompanied a reduction in $\mathrm{CO}_{2}$ exchange in $T$. ionantha. Different environmental conditions during the drought treatments may help to explain this difference in results.

In the current study, nocturnal malic acid accumulations remained high throughout the drought treatment, apparently because of the recycling of respiratory $\mathrm{CO}_{2}$ via CAM. Even in well-watered plants, ca. $22 \%$ of the malic acid accumulated was derived from internal $\mathrm{CO}_{2}$. Although little or no $\mathrm{CO}_{2}$ recycling was reported in well-watered $T$. ionantha in a previous study (Loeschen et al. 1993), high levels of $\mathrm{CO}_{2}$ recycling have been reported for well-watered individuals of Tillandsia elongata and Tillandsia utriculata (Griffiths et al. 1986), Tillandsia flexuosa (Griffiths et al. 1989), and T. schiedeana (Martin and Adams 1987; Loeschen et al. 1993).

This study indicated that contributions to nocturnal malic acid accumulation from respired $\mathrm{CO}_{2}$ increased with increasing days of desiccation. This increase in $\mathrm{CO}_{2}$ recycling explains the observation that malic acid accumulations remained high even after $50 \mathrm{~d}$ without water, despite the fact that integrated $\mathrm{CO}_{2}$ uptake declined dramatically. Increases in $\mathrm{CO}_{2}$ recycling with increasing levels of stress have been reported previously for other bromeliads and nonbromeliads as well (Martin and Adams 1987; Griffiths 1988; Griffiths et al. 1989; Fetene and Lüttge 1991).

Changes in WATER RElations AND CAM DURING THE DROUGHT TREATMENT

Decreasing nocturnal $\mathrm{CO}_{2}$ uptake, increasing levels of $\mathrm{CO}_{2}$ recycling, and decreasing osmotic potentials (possibly reflecting osmotic adjustment) observed in $T$. ionantha after $30 \mathrm{~d}$ are characteristic responses of many CAM plants to drought stress (Griffiths et al. 1986; Lüttge 1987; Smith 1989; Martin 1994). Both leaf water potentials and relative water contents declined during the drought treatment, as did nighttime $\mathrm{CO}_{2}$ uptake. During the initial stages of the drought treatment (0-30 d without water), water potentials did not change, while relative water content declined in a linear fashion. In contrast, both water potential and relative water content declined significantly from 40 through $60 \mathrm{~d}$ without water. Both integrated $\mathrm{CO}_{2}$ uptake and nocturnal increases in tissue malic acid concentrations remained constant until midway through the drought treatment, then declined significantly thereafter. These findings do not support recent suggestions that relative water content may be a better indicator of the physiological state of a plant than tissue water potential (Sinclair and Ludlow 1985; Passioura 1988).

\section{POTENTIAL MECHANISMS MINIMIZING WATER LOSS DURING THE DROUGHT TREATMENT}

Plants of $T$. ionantha appear to be highly resistant to desiccation. For example, leaf relative water content declined by only $20 \%$ after $20 \mathrm{~d}$ without water in this study. This value can be compared with declines in relative water content of ca. $70 \%$ for leaves of the $\mathrm{C}_{3}$ fern Pyrrosia angustata and declines of ca. 30\% for leaves of the CAM orchid Eria velutina during a 20-d drought treatment in the field in southeastern Australia (Sinclair 1983).

Potential mechanisms underlying the maintenance of relatively high tissue water content in $T$. ionantha include the following. First, like many succulents in arid habitats, $T$. ionantha is a CAM plant that is undoubtedly responsible, at least in part, for its high water-use efficiency (C. E. Martin, unpublished data), as is the case with many atmospheric bromeliads (Lüttge et al. 1986; Smith et al. 1986b; Griffiths et al. 1989). Second, the morphology of leaves of $T$. ionantha may impart restrictions on water loss. Stomatal densities of leaf epidermi are $6 \mathrm{~mm}^{-2}$, and stomatal length and width are 37 and $41 \mu \mathrm{m}$, respectively (Martin 1994). All of these values are much smaller than those of terrestrial nonbromeliads, as well as many other bromeliad taxa (Martin 1994). Third, leaves of T. ionantha are covered by a dense layer of epidermal trichomes that may restrict water loss by increasing the thickness of the boundary layer (Benzing 1980, 1986).

\section{Potential MECHANISMS MAINTAINING PHYSIOLOGICAL ACTIVITY DURING MILD DROUGHT STRESS}

Although leaf relative water content declined linearly throughout the drought treatment, leaf water potential remained high for up to 20-30 d without water. As indicated above, changes in net $\mathrm{CO}_{2}$ exchange of the plants mirrored these changes in water potential, not those of relative water content. These findings may help to explain the previously reported puzzling result that physiological activity in these epiphytes is unaffected by substantial amounts of tissue water loss (see above and Martin 1994), presumably because cell turgor in the leaves is maintained at relatively high levels. A potential explanation for the maintenance of high leaf water potentials (and, hence, turgor) while water content declines involves the specialized leaf anatomy of $T$. ionantha. The water content of the chlorenchyma, the actively metabolizing region of the leaf, remained high throughout most of the drought treatment, thus preserving physiological activity. In $T$. ionantha, which has well-developed hydrenchyma tissue, the hydration of the chlorenchyma is apparently maintained at the expense of the hydrenchyma. Throughout the drought treatment, amounts of water loss were apparently substantially greater for the hydrenchyma tissue than for the chlorenchyma. Similar results have been reported previously for several terrestrial succulents (Barcikowski and Nobel 1984; Schmidt and Kaiser 1987; Goldstein et al. 1991b). As a result of these anatomical changes, the water potential of the chlorenchyma becomes increasingly more representative of that of the whole leaf as the hydrenchyma tissue shrinks.

The preferential loss of water from the hydrenchyma to the chlorenchyma may be attributable to a com- 
bination of two factors: differences in osmotic potential and differences in cell wall elasticity between the two tissues (Zimmermann 1978; Barcikowski and Nobel 1984; Meinzer et al. 1986; Schmidt and Kaiser 1987; Schulte and Nobel 1989; Goldstein et al. 1991a).

\section{POTENTIAL MECHANISMS MAINTAINING PHYSIOLOGICAL ACTIVITY DURING SEVERE DROUGHT STRESS}

After $60 \mathrm{~d}$ without water, the water potential of leaves of $T$. ionantha had declined only to $-0.64 \mathrm{MPa}$. Such a relatively high value after a 2 -mo drought treatment agrees well with several other previous investigations of the water relations of atmospheric epiphytes (see Martin 1994). These findings are not unique to epiphytic bromeliads; they also characterize the response of many terrestrial succulents to drought (Szarek and Ting 1974; Nobel 1988; Goldstein et al. 1991b).

Relative declines in photosynthetic activity during the drought treatment appeared to reflect changes in the amount of chlorenchyma more than in the amount of hydrenchyma. Not surprisingly, declining water content in regions of actively photosynthesizing tissue has been shown in numerous studies to inhibit photosynthetic capacity (Hanson and Hitz 1982; Kaiser 1982; Santakumari and Berkowitz 1991).

Once drought stress was severe enough to affect physiological activity in $T$. ionantha, osmotic adjustment occurred. A decrease in osmotic potential of 0.27 $\mathrm{MPa}(57 \%$ change) was observed from 40 through 60 $\mathrm{d}$ without water. Because substantial changes in osmotic potential did not occur until day 40 of the drought treatment, this osmotic adjustment did not play a significant role in maintaining high photosynthetic rates during the first $30 \mathrm{~d}$ of the drought treatment. The maintenance of a constant osmotic potential as the leaf tissue lost water (cf. figs. 1, 3) indicates that the changing osmotic potential later in the drought treatment reflected, at least in part, true osmotic adjustment and not a simple concentration of solutes due to tissue desiccation. The level of osmotic adjustment observed in the current study may have played an important role in maintaining relatively high cell turgor, and hence possibly photosynthetic activity, during the latter stages of the drought treatment (Turner and Jones 1980)

High cell wall elasticities in the leaf may also contribute to the maintenance of high water potentials during droughts; however, such values for leaves of epiphytic bromeliads are rare. Stiles and Martin (1996) measured a very high cell wall elasticity (low bulk elastic modulus) for leaves of the atmospheric epiphyte
T. utriculata. Such high values may also be characteristic of the congener $T$. ionantha.

\section{Possible BENEFIT OF $\mathrm{CO}_{2}$ RECYCLING VIA CAM}

Although various hypotheses have been presented to account for potential benefits of $\mathrm{CO}_{2}$ recycling during CAM, it seems likely that this phenomenon probably acts as a precursor to CAM-idling (Ting and Rayder 1982; Ting 1985; Martin 1996). The latter process is characteristic of severely stressed CAM plants and presumably benefits a plant by minimizing photoinhibition and by maintaining the plant in a metabolically active state during severe droughts (Ting 1985; Martin 1994). Thus, this process may constitute an adaptation contributing to the apparent drought resistance of $T$. ionantha during periods of extreme desiccation.

\section{Conclusion}

In summary, the effects of drought on Tillandsia ionantha can be separated into two phases. An early phase (0-20 d in this experimental drought treatment) was observed during which osmotic potential, water potential, malic acid accumulation, and $\mathrm{CO}_{2}$ exchange remained relatively constant in spite of some tissue water loss. Minimization of water loss during this period most likely resulted from daytime stomatal closure and leaf morphological features. Maintenance of high water potentials, and, hence, physiological activity (high nocturnal $\mathrm{CO}_{2}$ uptake rates and accumulations of malic acid) in this early phase was attributed to hydration of the chlorenchyma as a result of water movement from the hydrenchyma. In the later phase $(30-60 \mathrm{~d})$ of the drought treatment, the water content of the chlorenchyma apparently declined enough to impair photosynthesis. Maintenance of some photosynthetic activity under drought stress was attributed to osmotic adjustment and a potentially high cell wall elasticity.

The results of this study have provided added insight into some of the possible mechanisms of drought tolerance in the atmospheric bromeliad $T$. ionantha. Clearly, the diverse nature of physiological and anatomical adaptations that apparently minimize the severity of drought stress in this species is indicative of the importance of drought in the evolution of these epiphytic taxa.

\section{Acknowledgments}

We gratefully acknowledge the support and assistance of K. Arthurs throughout this research. The generosity of W. John Kress and the Marie Selby Botanical Gardens for supplying the plants is also appreciated.

\section{Literature cited}

Adams WW III, CE Martin 1986 Physiological consequences of changes in leaf form of the Mexican epiphyte Tillandsia deppeana (Bromeliaceae). Oecologia 70:298-304.

Barcikowski W, PS Nobel 1984 Water relations of cacti during desiccation: distribution of water in tissues. Bot Gaz 145:110-115.
Benzing DH 1980 The biology of the bromeliads. Mad River, Eureka, Calif. 305 pp.

1986 The vegetative basis of vascular epiphytism. Selbyana 9:23-43.

Benzing DH, CE Dahle 1971 The vegetative morphology, habitat 
preference and water balance mechanisms of the bromeliad Tillandsia ionantha Planch. Am Midl Nat 85:11-21.

Biebl R 1964 Zum Wasserhaushalt von Tillandsia recurvata L. und Tillandsia usneoides L. auf Puerto Rico. Protoplasma 58:345-368.

Conover WJ, RL Iman 1981 Rank transformations as a bridge between parametric and nonparametric statistics. Am Stat 35:124129.

Farquhar GD, TD Sharkey 1982 Stomatal conductance and photosynthesis. Annu Rev Plant Physiol 33:317-345.

Fetene M, U Lüttge 1991 Environmental influences on carbon recycling in a terrestrial CAM bromeliad, Bromelia humilis Jacq. J Exp Bot 42:25-31.

Gessner F 1956 Der Wasserhaushalt der Epiphyten und Lianen. Pages 915-950 in W Ruhland, ed. Handbuch der Pflanzenphysiologie, Band 3, Pflanze und Wasser. Springer, Berlin.

Goldstein G, JL Andrade, PS Nobel 1991 a Differences in water relations parameters for the chlorenchyma and the parenchyma of Opuntia ficus-indica under wet versus dry conditions. Aust J Plant Physiol 18:95-107.

Goldstein G, JKE Ortega, A Nerd, PS Nobel 1991b Diel patterns of water potential components for the Crassulacean acid metabolism plant Opuntia ficus-indica when well-watered or droughted. Plant Physiol 95:274-280.

Gravatt DA, CE Martin 1992 Comparative ecophysiology of five species of Sedum (Crassulaceae) under well-watered and droughtstressed conditions. Oecologia 92:532-541.

Griffiths H 1988 Carbon balance during CAM: an assessment of respiratory $\mathrm{CO}_{2}$ recycling in the epiphytic bromeliads Aechmea nudicaulis and Aechmea fendleri. Plant Cell Environ 11:603-611.

Griffiths H, U Lüttge, K-H Stimmel, CE Crook, NM Griffiths, JAC Smith 1986 Comparative ecophysiology of CAM and $C_{3}$ bromeliads. III. Environmental influences on $\mathrm{CO}_{2}$ assimilation and transpiration. Plant Cell Environ 9:385-393.

Griffiths H, JAC Smith, U Lüttge, M Popp, WJ Cram, M Diaz, HSJ Lee, E Medina, C Schäfer, K-H Stimmel 1989 Ecophysiology of xerophytic and halophytic vegetation of a coastal alluvial plain in northern Venezuela. IV. Tillandsia flexuosa Sw. and Schomburgkia humboldtiana Reichb., epiphytic CAM plants. New Phytol 111: 273-282.

Gutmann I, AW Wahlefeld 1974 L-(-)-malate: determination with malate dehydrogenase and NAD. Pages 1585-1589 in HU Bergmeyer, ed. Methods of enzymatic analysis. 2d English ed. Vol 3. Verlag Chemie, Weinheim, and Academic Press, New York.

Hanson AD, WD Hitz 1982 Metabolic responses of mesophytes to plant water deficits. Annu Rev Plant Physiol 33:163-203.

Harris JA 1918 On the osmotic concentration of the tissue fluids of phanerogamic epiphytes. Am J Bot 5:490-506.

Kaiser WM 1982 Correlation between changes in photosynthetic activity and changes in total protoplast volume in leaf tissue from hygro-, meso- and xerophytes under osmotic stress. Planta 154: $538-545$.

Kress WJ 1989 The systematic distribution of vascular epiphytes. Pages 234-261 in U Lüttge, ed. Vascular plants as epiphytes: evolution and ecophysiology. Springer, Berlin.

Loeschen VS, CE Martin, M Smith, SL Eder 1993 Leaf anatomy and $\mathrm{CO}_{2}$ recycling during Crassulacean acid metabolism in twelve epiphytic species of Tillandsia (Bromeliaceae). Int J Plant Sci 154: 100-106.

Lüttge U 1987 Carbon dioxide and water demand: Crassulacean acid metabolism (CAM), a versatile ecological adaptation exemplifying the need for integration in ecophysiological work. New Phytol 106:593-629.

Lüttge U, K-H Stimmel, JAC Smith, H Griffiths 1986 Comparative ecophysiology of CAM and $\mathrm{C}_{3}$ bromeliads. II. Field measurements of gas exchange of CAM bromeliads in the humid tropics. Plant Cell Environ 9:377-383.

Martin CE 1994 Physiological ecology of the Bromeliaceae. Bot Rev 60:1-82.

1996 Putative causes and consequences of recycling $\mathrm{CO}_{2}$ via Crassulacean acid metabolism. Pages 192-203 in K Winter, JAC Smith, eds. Crassulacean acid metabolism: biochemistry, ecophysiology and evolution. Springer, Berlin.

Martin CE, WW Adams III 1987 Crassulacean acid metabolism,
$\mathrm{CO}_{2}$-recycling, and tissue desiccation in the Mexican epiphyte Tillandsia schiedeana Steud (Bromeliaceae). Photosyn Res 11:237244.

Martin CE, NL Christensen, BR Strain 1981 Seasonal patterns of growth, tissue acid fluctuations, and ${ }^{14} \mathrm{CO}_{2}$ uptake in the Crassulacean acid metabolism epiphyte Tillandsia usneoides L. (Spanish moss). Oecologia 49:322-328.

Martin CE, AK Schmitt 1989 Unusual water relations in the CAM atmospheric epiphyte Tillandsia usneoides L. (Bromeliaceae). Bot Gaz 150:1-8.

Meinzer FC, PW Rundel, MR Sharifi, ET Nilsen 1986 Turgor and osmotic relations of the desert shrub Larrea tridentata. Plant Cell Environ 9:467-475.

Nobel PS 1988 Environmental biology of agaves and cacti. Cambridge University Press, Cambridge. $270 \mathrm{pp}$.

Nyman LP, JP Davis, SJ O'Dell, J Arditti, GC Stephens, DH Benzing 1987 Active uptake of amino acids by leaves of an epiphytic vascular plant, Tillandsia paucifolia (Bromeliaceae). Plant Physiol $83: 681-684$.

Osmond CB 1978 Crassulacean acid metabolism: a curiosity in context. Annu Rev Plant Physiol 29:379-414.

Passioura JB 1988 Response to Dr. P.J. Kramer's article, “Changing concepts regarding plant water relations," volume 11, number 7 , pp. 565-568. Plant Cell Environ 11:569-571.

Penfound WT, FG Deiler 1947 On the ecology of Spanish moss. Ecology 28:455-458.

Potvin C, DA Roff 1993 Distribution-free and robust statistical methods: viable alternatives to parametric statistics? Ecology 74 : $1617-1628$.

Richards PW 1952 The tropical rain forest. Cambridge University Press, London. 450 pp.

Santakumari M, GA Berkowitz 1991 Chloroplast volume: cell water potential relationships and acclimation of photosynthesis to leaf water deficits. Photosyn Res 28:9-20.

Schmidt JE, WM Kaiser 1987 Response of the succulent leaves of Peperomia magnoliaefolia to dehydration: water relations and solute movement in chlorenchyma and hydrenchyma. Plant Physiol 83:190-194.

Schulte PJ, PS Nobel 1989 Responses of a CAM plant to drought and rainfall: capacitance and osmotic pressure influences on water movement. J Exp Bot 40:61-70.

Šesták Z, J Čatský, PG Jarvis, eds 1971 Plant photosynthetic production: manual of methods. Junk, The Hague. 818 pp.

Sinclair R 1983 Water relations of tropical epiphytes. II. Performance during droughting. J Exp Bot 34:1664-1675.

Sinclair TR, MM Ludlow 1985 Who taught plants thermodynamics? the unfulfilled potential of plant water potential. Aust J Plant Physiol 12:213-217.

Slavík B 1974 Methods of studying plant water relations. Academic Publishing House of the Czech Academy of Sciences, Prague, and Springer, Berlin. 449 pp.

Smith JAC 1989 Epiphytic bromeliads. Pages 109-138 in U Lüttge, ed. Vascular plants as epiphytes: evolution and ecophysiology. Springer, Berlin.

Smith JAC, H Griffiths, M Bassett, NM Griffiths 1985 Day-night changes in the leaf water relations of epiphytic bromeliads in the rain forests of Trinidad. Oecologia 67:475-485.

Smith JAC, H Griffiths, U Lüttge 1986a Comparative ecophysiology of CAM and $C_{3}$ bromeliads. I. The ecology of the Bromeliaceae in Trinidad. Plant Cell Environ 9:359-376.

Smith JAC, H Griffiths, U Lüttge, CE Crook, NM Griffiths, K-H Stimmel $1986 b$ Comparative ecophysiology of CAM and $C_{3}$ bromeliads. IV. Plant water relations. Plant Cell Environ 9:395-410.

Smith JAC, U Lüttge 1985 Day-night changes in leaf water relations associated with the rhythm of Crassulacean acid metabolism in Kalanchoë daigremontiana. Planta 163:272-282.

Sokal RR, FJ Rohlf 1981 Biometry: the principles and practice of statistics in biological research. $2 \mathrm{~d}$ ed. WH Freeman, New York. $859 \mathrm{pp}$

Stiles KC, CE Martin 1996 Effects of drought stress on $\mathrm{CO}_{2}$ exchange and water relations in the CAM epiphyte Tillandsia utriculata (Bromeliaceae). J Plant Physiol 149:721-728. 
Szarek SR, IP Ting 1974 Seasonal patterns of acid metabolism and gas exchange in Opuntia basilaris. Plant Physiol 54:76-81.

Ting IP 1985 Crassulacean acid metabolism. Annu Rev Plant Physiol 36:595-622.

Ting IP, L Rayder 1982 Regulation of $\mathrm{C}_{3}$ to CAM shifts. Pages 193-207 in IP Ting, M Gibbs, eds. Crassulacean acid metabolism. American Society of Plant Physiologists, Rockville, Md.
Turner NC, MM Jones 1980 Turgor maintenance by osmotic adjustment: a review and evaluation. Pages $87-103$ in NC Turner, PJ Kramer, eds. Adaptation of plants to water and high temperature stress. Wiley, New York.

Zimmermann U 1978 Physics of turgor- and osmoregulation. Annu Rev Plant Physiol 29:121-148. 